\title{
DESAIN SUMBER BELAJAR MATEMATIKA BERBASIS APLIKASI ANDROID PADA MATERI PERBANDINGAN TRIGONOMETRI SEGITIGA SIKU-SIKU
}

\author{
Winaldi', Yenita Roza ${ }^{2}$, Maimunah ${ }^{3}$ \\ 1,2,3 Pendidikan Matematika, Universitas Riau, Kampus Bina Widya Jl. HR. Soebrantas, KM 12.5, Indonesia \\ vivipuspita.pendas@gmail.com
}

\begin{abstract}
Abstrak
Advancement of technology in 21 century give more challenges for the teachers in their best effort in developing mathematics learning sources based on technology. Microsoft powerpoint that commonly used by the teacher, it is combined with the android platform as the learning source. Android is one of the product of technology that already accepted by the people,so the effeciency of using it as the source of learning is very necessary. The aimed of the research for developing mathematics learning sources based on application of android by powerpoint that able give good and interesting visualization information in the material of the comparison of right triangle of trigonometry. The medhod of developing learning sources used model analysis design, development, implementation and evaluation (ADDIE). The result of the research create learning source design based on android application that was appropriate with the problems analysis and requirement that found in the school. Learning source based on android application design consist of several fitur such as objective of the study, material of study, the examples of questions and it's answers and the exercices or tasks.
\end{abstract}

Keywords : Design, Learning Source, Android, Trigonometry

\begin{abstract}
Abstrak
Kemajuan teknologi abad 21 memberikan tantangan tersendiri kepada guru dalam upaya mengembangkan sumber belajar matematika berbasis teknologi. Microsoft Powerpoint yang telah biasa digunakan oleh guru, kini dapat dipadukan dengan platform android sebagai sumber belajar. Android merupakan produk teknologi yang sudah diterima secara luas oleh masyarakat sehingga penggunaannya sebagai sumber belajar merupakan pilihan yang sangat tepat. Penelitian ini bertujuan untuk mengembangkan sumber belajar matematika berbasis aplikasi android melalui media Powerpoint yang mampu memberikan visualisasi yang baik dan menarik pada materi perbandingan trigonometri segitiga siku-siku. Metode pengembangan sumber belajar menggunakan model Analysis, Design, Development, Implementation dan Evaluation (ADDIE). Penelitian ini menghasilkan desain sumber belajar berbasis aplikasi android sesuai dengan analisis permasalahan dan kebutuhan yang ditemui di sekolah. Sumber belajar berbasis aplikasi android yang didesain terdiri dari beberapa fitur yakni tujuan pembelajaran, materi pembelajaran, contoh soal beserta jawaban dan latihan soal.
\end{abstract}

Kata Kunci : Pengembangan, Sumber Belajar, Android, Trigonometri

Dalam menghadapi era globalisasi dan penuh tantangan, saat ini diperlukan sumber daya manusia yang memiliki kemampuan tinggi dalam memecahkan berbagai masalah yang dihadapi. Seseorang yang memiliki kemampuan tinggi dapat dilihat dari cara berpikir yang logis, rasional, kritis dan kreatif. Kemampuan berpikir logis, rasional, kritis dan kreatif tidak terjadi dengan sendirinya, melainkan diperoleh melalui proses pendidikan khususnya pembelajaran matematika di sekolah. Matematika merupakan materi pelajaran yang mendapat perhatian khusus, karena matematika adalah dasar dari aplikasi dalam kehidupan sehari-hari. Arafani (2019) mengatakan bahwa matematika perlu diberikan kepada semua siswa mulai dari sekolah dasar untuk membekali mereka dengan kemampuan berpikir logis, analitis, sistematis, kritis dan kreatif serta kemampuan bekerja sama. 
Tanpa matematika sebuah bangsa tidak akan mampu menyapa alam semesta secara proporsional dan wajar (Liberna : 2012).

Penguasaan materi matematika bagi siswa menjadi suatu keharusan yang tidak bisa ditawar lagi. Pada kenyataannya matematika bukanlah mata pelajaran yang mudah dipahami begitu saja oleh siswa. Wahyu Rizki (2016) yang mengatakan bahwa matematika merupakan pelajaran yang memiliki peminat paling rendah dibandingkan pelajaran yang lain. Masalah ini disebabkan karena matematika dikenal sebagai pelajaran yang sulit sehingga tidak banyak orang yang menggemarinya. Rendahnya kemampuan dalam pembelajaran matematika dapat dilihat melalui hasil Ujian Nasional (UN) SMK bidang studi matematika pada tahun 2019 di Provinsi Riau, dengan jumlah peserta 28.692 Orang mendapatkan nilai rata-ratanya adalah 33.46. Rendahnya rata-rata nilai UN Matematika tersebut menunjukkan bahwa penguasaan terhadap materi matematika masih rendah dan belum mampu dipahami dengan baik oleh siswa.

Perbandingan trigonometri pada segitiga siku-siku merupakan salah satu materi dalam matematika yang sulit dipahami oleh siswa. Peserta didik cenderung kesulitan dalam menangkap konsep-konsep dalam materi tersebut karena dianggap rumit dan abstrak. Rendahnya pemahaman siswa dalam pembelajaran trigonometri dapat dilihat dari hasil ulangan harian yang dilakukan pada materi tersebut. Berdasarkan observasi yang dilakukan pada kelas X DPIB SMK negeri 3 Bengkalis, banyak siswa yang mendapatkan nilai ulangan dibawah Kriteria Ketuntasan Minimal (KKM). Minimnya hasil ulangan tersebut disebabkan oleh lemahnya pemahaman siswa terhadap materi perbandingan trigonometri pada segitiga siku-siku. Berdasarkan hasil ulangan yang dilaksanakan dapat dilihat bahwa siswa bermasalah dalam menentukan letak suatu sisi segitiga siku-siku berdasarkan suatu sudut.

Keberhasilan dalam pembelajaran trigonometri dipengaruhi oleh berbagai faktor, diantaranya adalah sumber belajar yang digunakan. Kondisi diberbagai sekolah menunjukkan bahwa saat ini banyak guru yang menggunakan buku teks sebagai satu-satunya sumber belajar. Yenita Roza (2018) mengatakan bahwa buku guru dan buku siswa yang disediakan pemerintah dirancang untuk tujuan nasional, guru perlu menyadari agar mereka dapat beradaptasi dengan karakteristik masing-masing sekolah. Didalam mempelajari perbandingan trigonometri pada segitiga siku-siku, sebaiknya menggunakan sumber belajar dan media yang mempu memberikan visualisasi yang menarik agar konsep-konsep abstrak yang terdapat didalam trigonometri dapat dipahami dengan mudah oleh siswa. Penggunaan buku teks cendrenung membawa kegiatan pembelajaran menganut ciri konvensional, dimana kegiatan belajar selalu terpusat kepada guru, dan siswa hanya menjadi pendengar.

Kepiawaian guru dalam mengembangkan sumber belajar melalui kecanggihan teknologi sangatlah diperlukan. Guru harus memiliki kemampuan untuk merencanakan, memilih dan menggunakan berbagai sumber belajar dan media pembelajaran untuk membuat pembelajaran menjadi lebih efektif. Memilih media dan sumber belajar yang dapat mendukung kegiatan pembelajaran adalah tanggung jawab guru (M. Saputra : 2018). Sumber belajar merupakan segala sesuatu yang digunakan untuk memfasilitasi belajar peserta didik (Evelin : 2011). Tujuan utama dari sumber belajar adalah 
Desain Sumber Belajar Matematika Berbasis Aplikasi Android Pada Materi Perbandingan Trigonometri Segitiga Siku-

membantu peserta didik dalam belajar, memahami, dan menguasai kemampuan dan keterampilan baru serta memotivasi siswa belajar lebih lanjut secara mandiri. Pengembangan sumber belajar merupakan hal yang sangat penting untuk diperhatikan. Terlebih di dalam pembelajaran matematika, sumber belajar dapat menjadi faktor penentu keberhasilan dalam rangka mencapai tujuan pembelajaran.

Pada abad ke-21 ini perkembangan ilmu pengetahuan dan teknologi sudah sangat pesat. Perkembangan ini juga mengubah paradigma pembelajaran di bidang Pendidikan (Ansari :2017). Kemajuan ilmu pengetahuan dan teknologi telah berpengaruh terhadap penggunaan alat-alat bantu mengajar di sekolah-sekolah dan lembaga-lembaga pendidikan lainnya (Ali :2010). Tuntutan era globalisasi dengan perkembangan teknologi informasi dapat dimanfaatkan untuk pengembangan pembelajaran. Salah satu hasil kemajuan teknologi di era 4.0 yang saat ini sangat familiar digunakan oleh guru adalah Microsoft Powerpoint. Microsoft PowerPoint adalah software yang dipakai untuk merancang bahan presentasi dalam bentuk slide. Menurut Arsyad (2012) Microsoft Powerpoint merupakan salah satu software yang dirancang khusus untuk menampilkan program multimedia yang menarik, mudah dalam pembuatan, mudah dalam penggunaan. Aplikasi ini menyediakan semua yang dibutuhkan untuk membuat aplikasi media pembelajaran (Yenita Roza :2017).

Randi (2015) mengatakan bahwa setidaknya terdapat beberapa alasan mengapa powerpoint baik digunakan untuk proses pembelajaran, yaitu: (1) penggunaan powerpoint dapat membantu baik guru maupun siswa, (2) dapat menghindari penggunaan kalimat yang berlebihan, (3) cocok untuk siswa dengan tipe belajar yang berbeda-beda, (4) mudah untuk dimodifikasi agar sesuai dengan kebutuhan siswa, (5) mudah untuk mengolah data pada setiap slide dan ekonomis, (6) mencetak data yang telah diolah dengan powerpoint dapat dilakukan dengan berbagai format dan variasi, (7) tidak membutuhkan kapasitas penyimpanan yang cukup besar. Berdasarkan beberapa alasan tersebut, maka di dalam pembelajaran matematika khususnya konsep abstrak sebaiknya memanfaatkan media komputer seperti Microsoft Powerpoint (Siti : 2016). Namun yang lebih menarik seiring berkembangnya teknologi, saat ini Microsoft Powerpoint tidak hanya dapat dijadikan sebagai media untuk melaksanakan presentasi saja, melainkan dapat dipadukan dengan sistem OS android dalam bentuk aplikasi sebagai sumber belajar yang lebih praktis tanpa harus menggunakan proyektor.

Dalam beberapa tahun terakhir, ponsel pintar telah lazim digunakan sebagai perangkat yang signifikan untuk mendukung dalam banyak aspek kehidupan (Kularbphettong : 2015). Mengingat mayoritas remaja saat ini sudah mengenal dan bahkan menggunakan OS Android dalam kehidupannya sehari-hari, tentu tidaklah sulit bagi seorang guru atau dosen untuk mengarahkan peserta didik untuk menggunakan ponsel pintar berbasis aplikasi Android dalam pembelajaran (Zuahir :2018). Pengembangan sumber belajar berbasis aplikasi android menjadi salah satu pilihan yang menarik dalam upaya meningkatkan keberhasilan dalam pembelajaran matematika khususnya pada materi trigonometri.

Romi Juli (2015) mengatakan bahwa sumber belajar matematika berbasis aplikasi android merupakan media pembelajaran alternatif yang memiliki karakteristik yang unik, yaitu dapat digunakan 
dimana saja dan kapan saja, serta didukung dengan visualisasi yang menarik. Danang Setyadi (2015) juga mengatakan bahwa penggunaan mobile learning berbasis android dalam pembelajaran matematika memiliki beberapa keunggulan, diantaranya 1) dapat dioperasikan dimanapun dan kapanpun, 2) meningkatkan motivasi peserta didik, dan 3) meningkatkan pembelajaran sesuai kebutuhannya . Berdasarkan permasalahan diatas, maka dibutuhkan suatu penelitian pengembangan sumber belajar matematika berbasis aplikasi android melalui Powerpoint pada materi perbandingan trigonometri segitiga siku-siku untuk membantu dan mempermudah guru dalam menyampaikan konsep-konsep materi yang sulit diterima oleh siswa.

\section{METODE}

Penelitian ini adalah penelitian pengembangan yang dimaksudkan untuk menghasilkan sumber belajar matematika berbasis aplikasi android melalui media powerpoint pada materi perbandingan trigonometri segitiga siku-siku. Model pengembangan dalam penelitian ini menggunakan ADDIE (Analysis, Design, Development, Implementation and Evaluation). Pada tahap ini peneliti mengembangkan produk masih dibatasi pada tahap analisis dan desain, lebih jelasnya, metode pengembangan dapat dilihat melalui bagan dibawah ini.

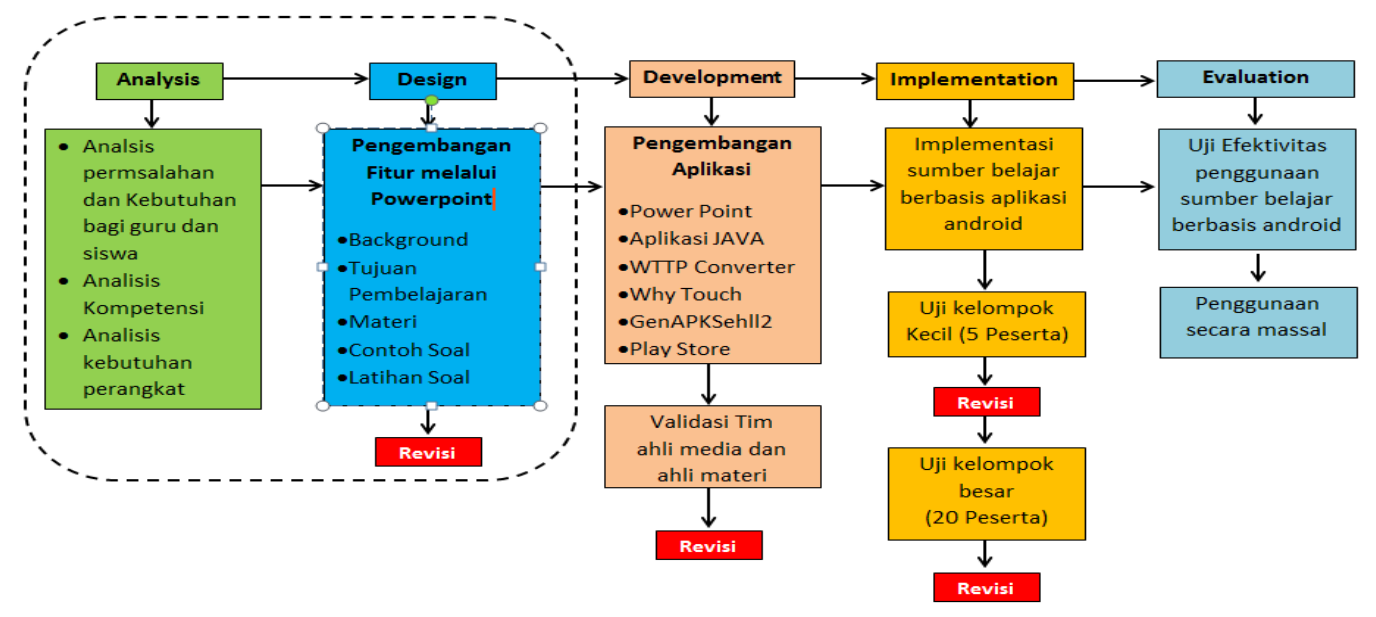

Gambar 1. Bagan Metode Penelitian

Tahap awal meliputi analisis permasalahan dan kebutuhan bagi siswa dan guru, analisis kompetensi, serta analisis kebutuhan perangkat lunak yang dibutuhkan. Analisis permasalahan dan kebutuhan bagi siswa dan guru meliputi permasalahan yang dihadapi oleh siswa serta rencana solusi yang ditawarkan. Analisis kompetensi berkaitan dengan kompetensi apasaja yang akan ditampilkan dalam sumber belajar. Selanjutnya, analisis software dan hardware berhubungan dengan kebutuhan teknologi untuk proses pengembangan media.

Tahap desain dilakukan dengan membuat desain tampilan aplikasi menggunakan slide pada Microsoft Powerpoint sesuai dengan kebutuhan dan mengatur ukuran slide, merencanakan warna background dari sumber belajar, jenis tulisan, ukuran tulisan, serta fitu-fitur yang akan disematkan pada media pembelajaran. Hal ini berkaitan dengan penentuan tujuan pembelajaran, kompetensi, 
Desain Sumber Belajar Matematika Berbasis Aplikasi Android Pada Materi Perbandingan Trigonometri Segitiga Siku-

materi, contoh soal, pembahasan soal dan latihan yang berkaitan dengan materi perbandingan trigonometri pada segitiga siku-siku.

\section{HASIL}

\section{Analisis Permasalahan dan Kebutuhan}

Tahap awal pengembangan dimulai dengan melakukan analisis permasalahan yang dialami oleh siswa dan guru dalam materi perbandingan trigonometri. Siswa mengalami kesulitan dalam menentukan letak sisi terhadap suatu sudut dalam segitiga siku-siku sehingga mengalami kesalahan dalam menentukan perbandingan trigonometri pada segitiga siku-siku tersebut. Masalah lain yang ditemukan adalah sumber belajar yang digunakan oleh guru juga kurang menarik dan masih belum menerapkan pembelajaran kontekstual, sehingga dibutuhkan suatu sumber belajar yang mampu memberikan visualisasi yang baik dalam menjelaskan materi tersebut. Melalui visualisasi yang baik dan menarik pada perangkat android diharapkan kegiatan pembelajaran menjadi lebih bermakna bagi siswa.

\section{Analisis Kompetensi}

Analisis kompetensi dilaksanakan dengan memilih dan menetapkan Kompetensi Dasar (KD) yang akan dikembangkan pada perangkat android. Kompetensi Dasar (KD) yang dipilih adalah KD 3.11. (menentukan perbandingan trigonometri pada segitiga siku-siku) dan KD 4.11 (menyajikan penyelesaian masalah yang berkaitan dengan perbandingan trigonometri pada segitiga siku-siku) pada kelas X SMK. Adapun beberapa kompetensi yang harus dimiliki oleh siswa melalui KD tersebut antara lain : (1) siwa menyebutkan definisi segitiga siku-siku, (2) menentukan unsur-unsur dari suatu segitiga siku-siku, (3) menyebutkan definisi perbandingan trigonometri, (4) menjelaskan secara lisan dan tertulis perbandingan trigonometri pada segitiga siku-siku serta menentukan nilai perbandingannya, dan (5) dapat menyelesaikan masalah kontekstual yang berkaitan dengan perbandingan trigonometri pada segitiga siku-siku.

\section{Analisis Kebutuhan Perangkat}

Setelah analisis permasalahan dan analisis kompetensi dilakukan, maka tahap selanjutnya adalah analisis kebutuhan terhadap softwere yang dibutuhkan dalam mengembangkan sumber belajar berbasis aplikasi android. Ada beberapa aplikasi yang dibutuhkan dalam mengembangkan sumber belajar berbasis aplikasi android, antara lain: (1) Microsoft Powerpoin sebagai wadah utama dalam mendesain tampilan sumber belajar, (2) Aplikasi Java Runtime Environment (JRE) sebagai aplikasi pendukung dalam sitem cooding., (3) Aplikasi WTPPT Converter yang berguna mengubah format PPT pada powerpoit menjadi fitur sentuh pada android, (4) Aplikasi whyTouch yang berguna sebagai penampil hasil pengubahan powerpoint menjadi fitur sentuh pada android dan (5) Aplikasi make APK yang memuat ApkGenShell2 yang berguna untuk Generate WTPTT menjadi apk yang dapat di install pada perangkat android. 


\section{Desain Sumber Belajar}

Pada tahap ini proses pengembangan sepenuhnya dilakukan pada microsoft powerpoint. Dimulai dengan pemilihan warna background, menentukan jenis tulisan, ukuran tulisan, jumlah slide, ukuran slide dan penamaan aplikasi sumber belajar. Pemberian background dan tulisan harus dibuat semenarik mungkin, hal ini bertujuan untuk memberikan kesan pertama yang menyenangkan bagi siswa dalam memulai kegiatan pembelajaran. Jumlah slide pada sumber belajar dibuat sesuai dengan kebutuhan untuk satu kali pertemuan. Slide pada sumber belajar terdiri dari beberapa halaman, yaitu tujuan pembelajaran, materi pembelajaran, contoh soal dan latihan soal. Adapun tampilan dan fiturfitur yang akan dibuat pada sumber belajar adalah sebagai berikut.

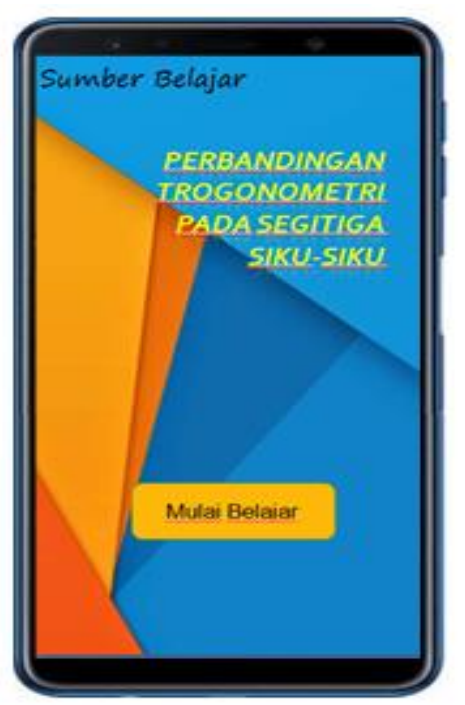

Gambar 2. Tampilan halaman utama

Gambar diatas merupakan tampilan halaman utama yang terdiri dari judul materi pembelajaran dan fitur pilihan "mulai belajar". Dengan memilih "mulai belajar" tampilan halaman utama akan berpindah ke halaman menu pilihan kegiatan pembelajaran.

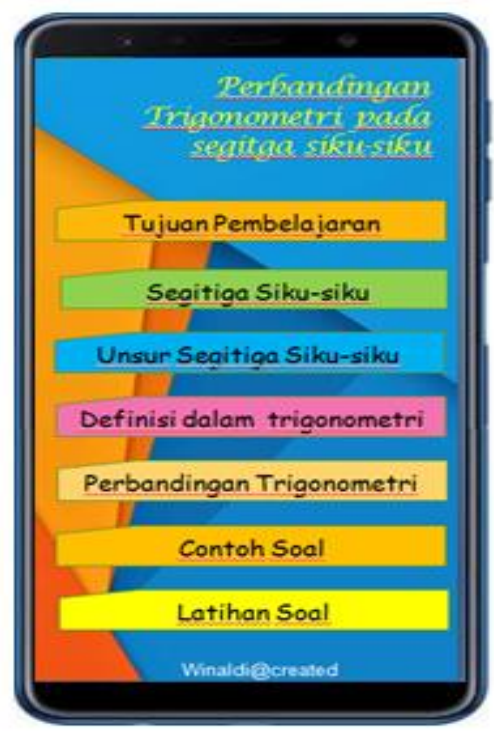

Gambar 3. Pilihan menu pembelajaran 
Desain Sumber Belajar Matematika Berbasis Aplikasi Android Pada Materi Perbandingan Trigonometri Segitiga SikuSiku, Winaldi, Yenita Roza, Maimunah

Pada halaman ini siswa dapat memilih menu diantaranya : Tujuan pembelajaran, materi segitiga siku-siku, unsur segitiga siku-siku, definisi dalam trigonometri, perbandinmgan trigonometri, contoh soal dan latihan soal.

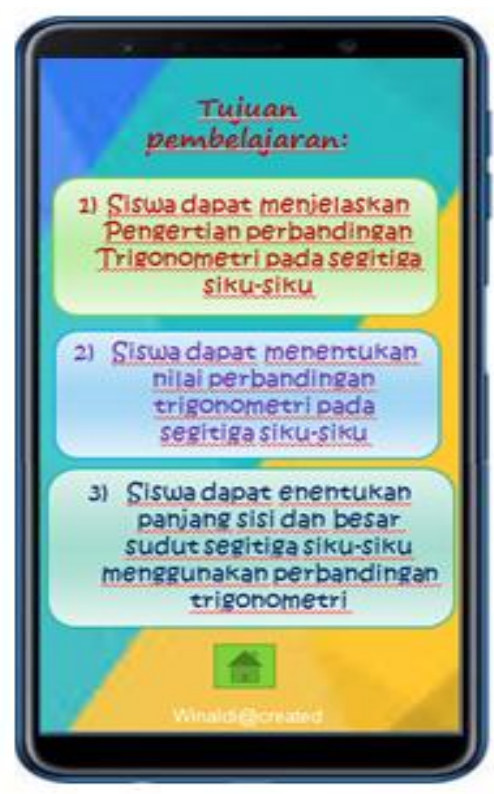

\section{Gambar 4. Tujuan Pembelajaran}

Tujuan pembelajaran menjelaskan tentang kompetensi apa yang harus dikuasai oleh siswa setelah kegiatan pembelajaran dilaksanakan. Berdasarkan analisis kompetensi terdapat minimal 3 kompetensi yang harus dikuasai oleh siswa, yaitu (1) siswa dapat menjelaskan perbandingan trigonometri pada segitiga siku-siku, (2) siswa dapat menentukan nilai perbandingan trigonometrinya, dan (3) siswa dapat menyelesaikan masalah yang berkaitan dengan perbandingan trigonometri pada segitiga siku-siku. Setelah memahami tujuan pembelajaran, untuk kembali ke halaman menu pembelajaran siswa dapat memilih "icon home" lalu dapat memilih apa yang akan dipelajari.

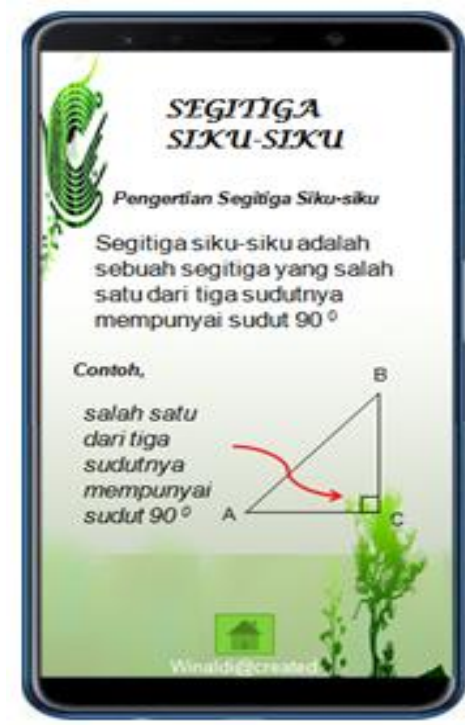

Gambar 5. Materi definisi segitiga siku-siku 
Gambar diatas merupakan menu pilihan definisi segitiga siku-siku. Sebelum memahami tentang perbandingan trigonometri pada segitigas iku-siku, siswa terlebih dahulu harus memahami definisi dan bentuk segitiga siku-siku. Dengan demikian siswa akan mengetahui bahwa perbandingan trigonometri hanya berlaku pada segitiga yang salah satu sudutnya adalah $90^{0 .}$ Untuk kembali ke menu pembelajaran siswa dapat memilih "icon home".

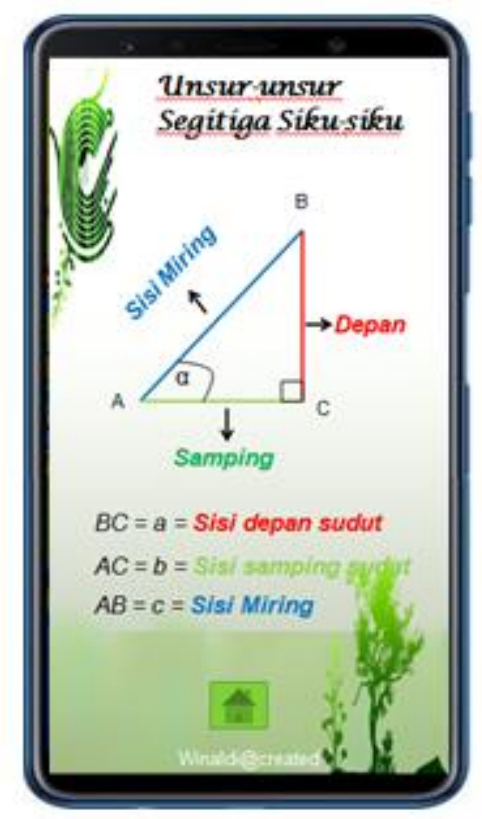

Gambar 6. Materi unsur-unsur segitiga siku-siku

Pada halaman ini dijelaskan unsur dari segitiga siku-siku. Siswa harus memahami letak suatu sisi terhadap sudut tertentu dalam segitiga siku-siku. karena ini akan menjadi acuan dalam menentukan perbandingan trigonometri pada segitiga siku-siku.

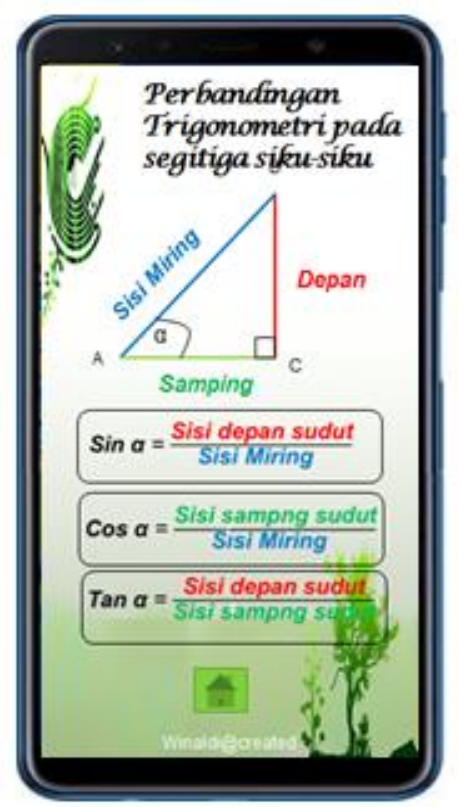

Gambar 7. Materi perbandingan trigonometri pada segitiga suku-siku 
Desain Sumber Belajar Matematika Berbasis Aplikasi Android Pada Materi Perbandingan Trigonometri Segitiga SikuSiku, Winaldi, Yenita Roza, Maimunah

Pada halaman ini terlihat visualisasi waarna yang berbeda pada msing-masing sisi segitiga, baik sisi depan sudut, dekat sudut dan sisi miring. Dengan demikian siswa akan lebih mudah mengingat perbandingan trigonometri pada segitiga siku-siku.

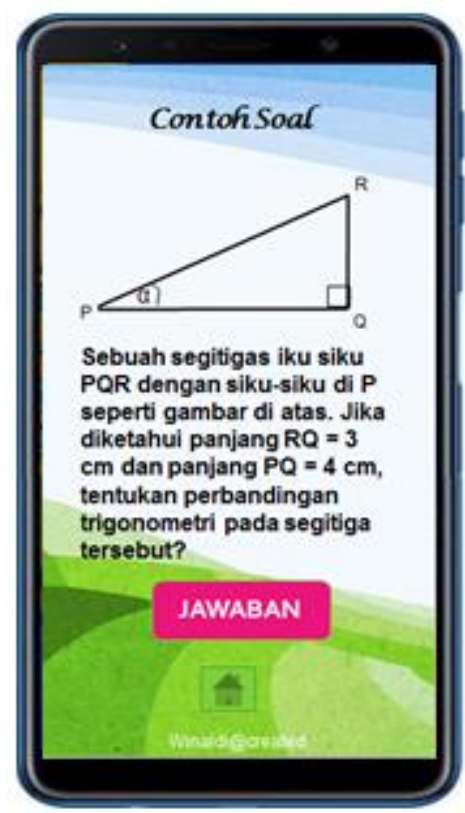

Gambar 8. Contoh Soal

Salah satu menu yang dapat dipilih siswa dalam menggunakan sumber belajar adalah contoh soal.

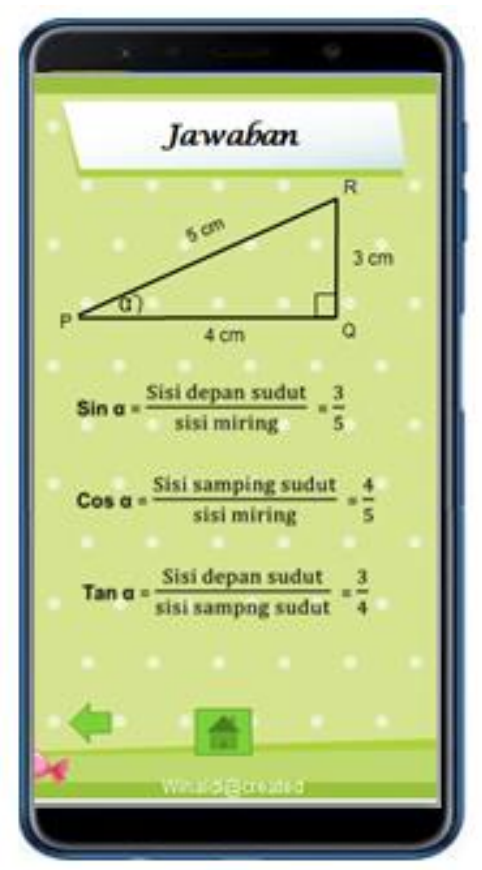

Gambar 9. Jawaban contoh soal

Jawaban dari contoh soal dapat membantu siswa belajar secara mandiri dengan mengikuti langkah-langkah yang dijelaskan pada jawaban. Jika kurang jelas, siswa dapat mengulang-ulang kembali materi yang kurang dipahami sesuai dengan kebutuhnannya. 


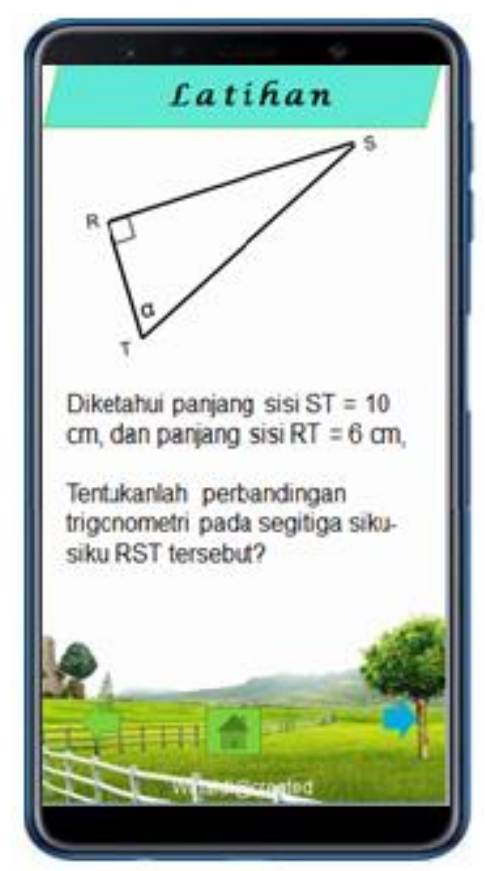

Gambar 10. Latihan soal

Latihan soal merupakan menu pilihan bagi siswa yang merasa tertantang dalam menyelesaikan latihan soal yang telah disediakan. Melalui latihan soal, diharapkan siswa dapat berdiskusi dan belajar secara mandiri.

\section{KESIMPULAN}

Aplikasi pengembangan sumber belajar matematika berbasis android diberi nama WIN MATH. Aplikasi dikembangkan berdasarkan alaisis permasalahan dan kebutuhan siswa dan guru pada materi perbandingan trigonometri pada segitiga siku-siku di kelas X SMK. Banyak perserta didik yang belum mampu menyelesaikan permasalahan pada materi tersebut sehingga dibutuhkan suatu sumber belajar yang menarik. Pengembangan sumber belajar berbasis aplikasi android dinilai mampu memberikan visualisasi yang baik dan menarik agar siswa lebih mudah dalam memahami materi perbadningan trigonometri pada segitiga siku-siku. Aplikasi ini dikembangkan dengan memanfaatkan program microsoft powerpoint mengingat saat ini hampir semua guru sudah mengenal program microsoft tersebut. Dengan demikian diharapkan semua guru dapat mengembangkan sumber belajar yang terintegrasi perkembangan teknologi terkini.

Penelitian pengembangan ini memfokuskan pada tahapan analisis dan desain. Penelitian selanjutnya dapat dilakukan pada tahap develompent, Implementation dan Evaluation. Dengan demikian sumber belajar benar-benar dapat digunakan langsung oleh siswa dalam upaya meningkatkan kemampuan dan pemahaman siswa pada materi perbandingan trigonometri pada segitiga siku-siku.

\section{DAFTAR PUSTAKA}

Ali Muhson. 2010. Pengembangan Media Pembelajaran Berbasis Teknologi Informasi. Jurnal Pendidikan Akuntansi Indonesia, Vol. VIII. No. 2 - Tahun 2010, Hlm.1- 10 
Desain Sumber Belajar Matematika Berbasis Aplikasi Android Pada Materi Perbandingan Trigonometri Segitiga Siku-

Ansari S. Ahmar. 2017. Development of teaching material using an Android. Global Journal of Engineering Education. Volume 19, Number 1.

Arafani, E. Lusiana. 2019. Peningkatan Kemampuan Pemecahan Masalah Matematika Siswa SMP dengan Pendekatan Kontekstual. Jurnal Cendikia : Jurnal Pendidikan Matematika. Volume 03. No. 02. Agustus 2019.

Arsyad, A. 2012. Media Pembelajaran. Jakarta: PT Raja Grafindo

Danang Setiadi. 2017. Pengembangan Mobile Learning Berbasis Android Sebagai Sarana Berlatih Mengerjakan Soal Matematika. DOI: 10.24246/ j.sw.2017.v33.i2.p87-92

Evelin dan Hartini. 2011. Teori Belajar dan Pembelajaran. Jakarta : Ghalia Indonesia

Hawa Liberna. 2012. Peningkatan Kemampuan Berpikir Kritis Matematis Siswa Melalui Penggunaan Metode Improve Pada Materi Sistem Persamaan Linear Dua Variabel. Jurnal Formatif Vol. 2, No.3: 190-197. ISSN: 2088-351X.

Kularbphettong, Kunyanuth. 2015. Developing of mLearning for Discrete Mathematics based on Android Platform. 7th World Conference on Educational Sciences, (WCES-2015), 05-07 February 2015, Novotel Athens Convention Center, Athens, Greece. Procedia - Social and Behavioral Sciences 197 ( 2015 ) $793-796$.

M. Saputra. 2018. The feasibility of an Android-based pocketbook as mathematics learning media in senior high school. Journal of Physics: Conf. Series 1088 (2018) 012056. IOP Publishing.

Muhammad Zuahir. 2018. Aplikasi Berbasis Android untuk Pembelajaran: Potensi dan Metode Pengembangan. Prisma Posiding Seminar Nasional Matematika.

OECD. 2016. PISA 2015 Results in Focus. New York: Columbia University

Randi Pratama. (2015). Pengembangan Perangkat Pembelajaran Matematika Model Problem-Based Learning Berbantuan Media Powerpoint Untuk Siswa Kelas Xi Smk Materi Barisan Dan Deret. Saintifika : Jurnal Imu Pendidikan dan Mipa. Vol.17 No. 2

Romi Julia. 2015. Pengembangan Aplikasi Android Sebagai Media Pembelajaran Matematika Pada Materi Dimensi Tiga Untuk Siswa Sma Kelas X. Jurnal Pendidikan Matematika FMIPA UM.

Setiyani. 2019. Designing educational game android to improve mathematical understanding ability on fraction. The Sixth Seminar Nasional Pendidikan Matematika Universitas Ahmad Dahlan 2018. Journal of Physics: Conf. Series 1188 (2019) 012067. IOP Publishing.

Siti Marfuah. (2016). Pengembangan media pembelajaran menggunakan powerpoint disertai visual basic for application materi jarak pada bangun ruang kelas $x$. Jurnal Gantang : Pendidikan Matematika. Vol. 1 No. 1

Wahyu Rizki. (2016). Pengembangan Bahan Ajar Materi Trigonometri Berbantuan Software iMind Map pada Siswa SMA. Aljabar : Jurnal Pendidikan Matematika. Vo. 7 No. 1 hal. 39-47.

Yenita Roza. (2017). Computer-Based Media for Learning Geometry at Mathematics Class of Secondary Schools. Journal of Educational Sciences. Vol. 1, No. 1, 2017, 79-91 
Yenita Roza. (2018). Android based e-learning tutorial for mathematics teachers. Journal of Physics: Conf. Series. The 6th South East Asia Design Research International Conference (6th SEA-DR IC). 